\title{
Reacties van COSO op de maatschappij van nu.
}

\section{De geüpdate versie van het framework voor internal control,}

\section{een grote sprong voorwaarts of (te) veel mooie woorden?}

Jan Droogsma

SAMENVATTING Het Committee of Sponsoring Organizations of the Treadway Commission (COSO) heeft op 14 mei 2013 een geüpdate versie van het Internal Control - Integrated Framework (IC-framework 2013) uitgebracht. De vraag die in dit artikel centraal staat is: Wat is de toegevoegde waarde van dit geüpdate framework ten opzichte van het eerder in $1992^{1}$ door COSO uitgebrachte framework voor Internal Control (IC-framework 1992)? Op basis van een toelichting van de verschillen tussen de beide versies van het IC-framework en een analyse in hoeverre met het ICframework 2013 tegemoetgekomen is aan de kritiekpunten op het IC-framework 1992 wordt de conclusie getrokken dat dit geüpdate framework in opzet een grote sprong voorwaarts is wat internal control betreft. Sterke punten van het IC-framework 2013 zijn het nader invullen van de componenten van internal control door middel van principes en aandachtspunten en de extra aandacht die is besteed aan de betrouwbaarheid van niet-financiële informatie, expertise van toezichthouders, andere organisatievormen, het functioneren in netwerken, uitbesteding van activiteiten aan shared service centers, het toepassen van beloningssystemen, het gebruik van soft controls, het signaleren van frauderisico's en de toepassing van actuele ICTsystemen. Ook zijn veel kritiekpunten uit de literatuur met betrekking tot het ICframework weggenomen met het geüpdate framework. In de praktijk zal echter moeten blijken in hoeverre organisaties in staat zijn op basis van deze principes te komen tot een efficiënt en effectief functionerend internalcontrolsysteem. Hiervoor is ook een bijdrage vanuit de wetenschap van belang.

RELEVANTIE VOOR DE PRAKTIJK COSO heeft op 14 mei 2013 een update van het IC-framework uit 1992 uitgebracht. In dit artikel worden de verschillen van deze update ten opzichte van het IC-framework uit 1992 toegelicht en wordt nagegaan in hoeverre met deze update de bestaande kritiek op het IC-framework 1992 is weggenomen. Op basis hiervan kunnen toezichthouders, managers en hun controllers nagaan in hoeverre deze update een aanleiding is om te komen tot aanpassingen van de interne beheersing van hun organisaties. Organisaties die het IC-framework al toepassen kunnen op basis van de principes en aandachtspunten uit het geüpdate framework tot een doeltreffender internal control komen, die veel meer gefocust is op het succes van de organisatie en leidt tot een hogere acceptatie van de voorgeschreven controls.

\section{Inleiding}

Op 14 mei 2013 heeft COSO een geüpdate versie van het Internal Control - Integrated Framework uit 1992 uitgebracht. Over de kwaliteit van het IC-framework 1992 als richtlijn voor het beoordelen en verbeteren van internal control verschillen de meningen van gebruikers. Gupta en Thomson (2006) geven bijvoorbeeld aan dat dit framework te vaag en te abstract is, wat leidt tot verwarring en hoge kosten bij de toepassing ervan. Het IC-framework 1992 was indertijd een belangrijke mijlpaal op het gebied van internal control omdat het een antwoord was op het verzoek van de $\mathrm{Na}$ tional Commission on Fraudulent Financial Reporting (de Treadway Commissie) aan COSO om de verschillende bestaande concepten en definities van internal control te integreren in een eenduidig referentiekader. Dit verzoek is gedaan als reactie op een onderzoek van de commissie naar frauduleuze verslaggeving in de periode oktober 1985 tot september 1987. In die tijd was frauduleuze verslaggeving ook al een serieus probleem (National Commission on Fraudulent Financial Reporting, 1987). Het IC-framework 1992 bevat een algemeen geaccepteerde definitie van het begrip internal control en een model dat gebruikt kan worden voor de implementatie, de beoordeling en de verbetering van het systeem van internal control van organisaties.

Het IC-framework 1992 is later, rond de eeuwwisseling, ook als referentiekader voor internal control op- 
Tabel 1 De principes uit het IC-framework 2013 (COSO, 2013, p.18)

\section{De principes per component van intern control uit het framework 2013}

\section{Control Environment}

1. The organization demonstrates a commitment to integrity and ethical values

2. The board of directors demonstrates independence from management and exercises oversight for the development and performance of internal contro

3. Management establishes, with board oversight, structures, reporting lines and appropriate authorities and responsibilities in the pursuit of objectives

4. The organization demonstrates a commitment to attract, develop, and retain competent individuals in alignment with objectives

5. The organization holds individuals accountable for their internal control responsibilities in the pursuit of objectives

Risk assessment

6. The organization specifies objectives with sufficient clarity to enable the identification and assessment of risks relating to the objectives

7. The organization identifies risks to the achievement of its objectives across the entity and analyzes risks as a basis for determining how the risks should be managed

8. The organization considers the potential for fraud in assessing risks to the achievement of objectives

9. The organization identifies and assesses changes that could significantly impact the system of internal contro

\section{Control activities}

10. The organization selects and develops control activities that contribute to the mitigation of risks to the achievement of objectives to acceptable levels

11. The organization selects and develops general control activities over technology to support the achievement of objectives

12. The organization deploys control activities through policies that establish what is expected and procedures that put policies into action

Information and communication

13. The organization obtains or generates and uses relevant quality information to support the functioning of other components of internal control

14. The organization internally communicates information, including objectives and responsibilities for internal control, necessary to support the functioning of internal control

15. The organization communicates with external parties regarding matters affecting the functioning of internal control

Monitoring

16. The organization selects, develops and performs ongoing and/or separate evaluations to ascertain whether the components of internal control are present and functioning

17. The organization evaluates and communicates internal control deficiencies in a timely manner to those parties responsible for taking corrective actions, including senior management and the board of directors, as appropriate

genomen in de corporate governance wet- en regelgeving, zoals met betrekking tot de Sarbanes-Oxley regelgeving in Auditing Standard No 5 van de Public Company Accounting Oversight Board (PCAOB) (PCAOB, 2007, p. A1-5; Savage et al., 2008) en de Nederlandse Corporate Governance Code (Monitoring Commissie Corporate Governance Code, 2008, p. 39).

Gegeven de kritiek op het IC-framework 1992 en de ontwikkelingen die sinds het uitbrengen van deze versie van het IC-framework hebben plaatsgevonden in organisaties en in de maatschappij, was er behoefte aan een update van het IC-framework 1992.

Het is dan ook een goede ontwikkeling dat een belangrijk internationaal referentiekader voor internal control als het Internal Control - Integrated Framework van COSO is geactualiseerd. Interessant is het om te weten in hoeverre deze update een goede bijdrage kan leveren aan het verbeteren van de internal control bij organisaties of dat het een verzameling van mooie woorden is waar we niet veel mee opschieten. Deze vraag staat centraal in dit artikel.

Op basis van een toelichting van de verschillen tussen de beide versies van het IC-framework en een analyse in hoeverre met het IC-framework 2013 tegemoetgekomen is aan de kritiekpunten op het IC-framework 1992 wordt deze vraag beantwoord.

Dit artikel is als volgt opgebouwd. In paragraaf 2 wordt een overzicht gegeven van de verschillen tussen de beide IC-frameworks. In paragraaf 3 wordt ingegaan op de kritiekpunten op het IC-framework 1992 en wordt toegelicht in hoeverre de kritiekpunten zijn weggenomen met het uitbrengen van het IC-framework 2013. Paragraaf 4 bevat de conclusie over de toegevoegde waarde van het IC-framework 2013 ten opzichte van het IC-framework uit 1992. Deze conclusie is het antwoord op de centrale vraag die de basis vormt van dit artikel. Ik zal eindigen met suggesties voor verder onderzoek naar aanleiding van vraagpunten.

\section{De verschillen tussen het IC-framework 1992 en het IC-framework 2013}

De meest fundamentele aanpassing is dat het ICframework 2013 is uitgebreid met 17 principes die de basis vormen voor de in 1992 vastgestelde componenten van internal control. Dit maakt de opzet van het framework veel toegankelijker en laat meer ruimte open voor toepassingen bij kleinere organisaties en in specifieke omstandigheden, zonder dat het doel van het framework verloren gaat. Tevens is aan de doelstellingen van het framework 2013 ook de betrouwbaarheid van de niet-financiële informatie toegevoegd. Een overzicht van de principes is opgenomen in tabel 1 .

Uitgangspunt van het IC-framework 2013 is dat management onderbouwde keuzes moet maken welke principes wel en niet worden aangehouden om in control te zijn. Voor toezichthouders als het audit committee is de onderbouwing van deze keuzes van groot belang. Op basis van deze informatie kunnen toezichthouders nagaan of de keuze, wat hun betreft, verantwoord is voor een toereikende control van de doelstellingen van de organisatie.

In het vervolg van deze paragraaf worden de principes en de onderliggende aandachtspunten nader toegelicht. Hierbij ligt het accent op de updates.

1. The organization demonstrates a commitment to integrity and ethical values 
Dit principe betreft de elementen "tone at the top" en de code of conduct. Het element "tone at the top" is in het IC-framework 2013 meer uitgewerkt dan in het ICframework 1992. Het gaat om waarden, een leiderschapsfilosofie en een wijze van werken die in lijn ligt met de doelstellingen van de organisatie. Deze waarden, zo wordt aangegeven, zijn afgestemd op de belangen van de stakeholders van de organisatie, inclusief de maatschappelijke impact van de organisatie. Verder wordt een aantal elementen aangegeven waarin de "tone at the top" op enigerlei vorm naar voren kan komen. Dit betreft (COSO, 2013, p. 66):

- de missie en uitingen van de geldende waarden;

- standaarden en gedragscodes;

- beleid en praktijken;

- werkwijzen, aanwijzingen, richtlijnen en andere uitingen van communicatie;

- acties en besluitvorming van het management op de diverse plaatsen in de organisatie en van de hoogste leiding;

- houding ten opzichte van en reacties op afwijkingen van verwacht gedrag en de codes;

- informele en routinematige contacten van leiders op de diverse niveaus binnen de organisatie.

Hierbij wordt een link gelegd met uitbestede activiteiten aan shared service centers en samenwerking met andere partners in netwerken van de organisatie. Deze punten zijn vertaald naar te implementeren en te evalueren punten om de mate van "in control" te realiseren respectievelijk te onderbouwen.

2. The board of directors demonstrates independence from management and exercises oversight for the development and performance of internal control

Dit principe heeft betrekking op onafhankelijkheid en relevante expertise van toezichthouders. Voor toezichthouders worden de volgende kennis en vaardigheden aanbevolen (COSO, 2013, p. 74): internal control (waaronder een professioneel kritische houding en affiniteit met risicomanagement), marketing, bedrijfskunde, financiën (inclusief verslaggeving), juridisch, sociaal en omgevingsbewustzijn, incentives en beloningssystemen en informatie- en communicatietechnologie (ICT). Dit leidt tot beter toezicht en goede discussies tussen de toezichthouder en het management over de risico's, de effectiviteit van de strategie van de organisatie, de beheersingsmaatregelen en de kwaliteit van de verslaggeving. In het IC-framework 1992 is deze aanbeveling niet opgenomen.

3. Management establishes, with board oversight, structures, reporting lines and appropriate authorities and responsibilities in the pursuit of objectives

Dit principe heeft betrekking op rapportage- en verantwoordingslijnen door de gehele organisatie en de aansluiting hiervan op de doelstellingen van de organisatie. Hiermee wordt een goede basis gelegd voor de component Information and Communication. Voor dit principe worden concrete inrichtings- en evaluatiepunten genoemd die zijn toegespitst op de aard en omvang van de activiteiten van de organisatie, de risico's die verbonden zijn met de doelstellingen van de organisatie en de processen, ongeacht of ze zijn uitbesteed, gedecentraliseerd of op enig niveau binnen de organisatie zijn geconcentreerd. Deze evaluatiepunten kunnen worden gebruikt voor de implementatie van rapportage- en verantwoordelijkheidslijnen en om vast te stellen in hoeverre de organisatie in control is.

Bij het uitwerken van dit principe is, wat deze punten betreft, in het IC-framework 2013 meer rekening gehouden met de grotere variëteit aan organisatiestructuren en de uitbesteding van activiteiten aan serviceorganisaties dan in het IC-framework 1992. De elementen van de control environment "organisatiestructuur" en "toewijzing van verantwoordelijkheden” zijn anders omschreven. In het IC-framework 2013 is aangegeven dat: "Senior management and the board of directors establish the organizational structure and reporting lines necessary to plan, execute, control and periodically assess the activities of the entity. They are supported by requisite processes and technology to provide for clear accountability and information flows within and across the overall entity and its subunits" (COSO, 2013, p. 77). Aangegeven wordt dat organisaties via diverse dimensies zijn ingericht. Ingegaan wordt op externe partijen die de realisatie van de doelstellingen ondersteunen en waarvoor afzonderlijke structuren en rapportagelijnen moeten worden ingericht. Er wordt gesteld dat de rapportagelijnen en communicatiekanalen de verantwoording over de uitvoerende eenheden en functionele gebieden mogelijk moeten maken.

In het kader van de beperking van de bevoegdheden wordt het three-lines-of-defensemodel geïntroduceerd. Hiermee wordt een goede balans gecreëerd tussen het management en het directe personeel, de ondersteunende controlfunctie en de auditfunctie die de internal control beoordeelt en daarover rapporteert en aanbevelingen doet op dit gebied.

Benadrukt wordt dat het van groot belang is dat periodiek wordt geëvalueerd in hoeverre de bestaande structuren aansluiten op gewijzigde prioriteiten.

4. The organization demonstrates a commitment to attract, develop, and retain competent individuals in alignment with objectives

Bij dit principe wordt meer aandacht besteed aan de ontwikkeling en de continuiteit van personeel van de organisatie dan in het IC-framework 1992. 
5. The organization holds individuals accountable for their internal control responsibilities in the pursuit of objectives

Dit principe heeft betrekking op de verantwoordelijkheid voor internal control, performance-indicatoren, incentive systemen en beloningen. Dit zijn allemaal elementen die de performance van de organisatie in belangrijke mate kunnen beïnvloeden. Met name de keuze van goede performance-indicatoren die in combinatie met de juiste prikkels en beloningen gericht zijn op het realiseren van de doelstellingen van de organisatie is een belangrijk punt dat in het IC-framework 2013 meer aandacht krijgt dan in het IC-framework 1992.

In het IC-framework 2013 wordt aangegeven dat prestatiemeting en beloningssystemen periodiek moeten worden gereviewd om na te gaan of deze nog steeds goed aansluiten op de doelstellingen van de organisatie en de verwachtingen van het management, het personeel en externe partijen (COSO, 2013, p. 89). Dit is een belangrijke maatregel om negatieve effecten van performancemeting en beloningssystemen op het succes van de organisatie tijdig te onderkennen. Er wordt ook gewaarschuwd voor negatieve effecten op het succes van de organisatie als gevolg van te grote druk op medewerkers. Performance moet worden gemeten in lijn met de te behalen doelstellingen en de risicobereidheid op de korte en de lange termijn.

6. The organization specifies objectives with sufficient clarity to enable the identification and assessment of risks relating to the objectives

De uitwerking van dit principe in het IC-framework 2013 is niet wezenlijk anders dan de vergelijkbare tekst in het IC-framework 1992.

7. The organization identifies risks to the achievement of its objectives across the entity and analyzes risks as a basis for determining how the risks should be managed

Bij dit principe wordt aandacht gevraagd voor de frequentie van risk assessments, aangezien de omgeving steeds sneller wijzigt. Dit komt in het IC-framework 2013 nadrukkelijker naar voren dan in het IC-framework 1992.

8. The organization considers the potential for frand in assessing risks to the achievement of objectives

Bij dit principe wordt aandacht besteed aan de zogenaamde fraudedriehoek ten behoeve van het onderkennen van frauderisico's. De theorie van de fraudedriehoek (Simons, 2000, pp. 269-273) gaat ervan uit dat mensen eerder fraude plegen als er een gelegenheid is om fraude te plegen, als er een cultuur of houding is waarin fraude niet echt wordt veroordeeld en er een rechtvaardiging is om fraude te plegen. Hiermee is in het IC-framework 2013 meer aandacht besteed aan de zachte factoren voor het herkennen van situaties met een verhoogde kans op fraudes dan in het IC-framework 1992.

9. The organization identifies and assesses changes that could significantly impact the system of internal control

Bij dit principe wordt aandacht besteed aan wijzigingen in de interne en externe omgeving en wordt aangegeven dat dit parallel moet lopen aan het risk assessment proces (COSO, 2013, p. 119). Dit is van groot belang voor de effectiviteit en actualiteit van het internalcontrolsysteem.

10. The organization selects and develops control activities that contribute to the mitigation of risks to the achievement of objectives to acceptable levels

De uitwerking van dit principe in het IC-framework 2013 is niet wezenlijk anders dan de vergelijkbare tekst in het IC-framework 1992.

11. The organization selects and develops general control activities over technology to support the achievement of objectives

Bij dit principe wordt ingegaan op het belang van goede controls voor de betrouwbare werking van technologie in processen van de organisatie. De nadere uitwerking van deze controls wijkt niet significant af van hetgeen hierover is uitgewerkt in het IC-framework 1992.

12. The organization deploys control activities through policies that establish what is expected and procedures that put policies into action

Dit principe heeft betrekking op het waarborgen van de werking van de control activities. Aangegeven wordt dat beleid inzake internal control, al dan niet op papier, moet zijn gekoppeld aan individuele verantwoordelijkheden en het afleggen van verantwoording en dat deze koppeling goed en zorgvuldig doordacht is, gericht op de specifieke risico's en dat de procedures tijdig, serieus en door deskundig personeel worden uitgevoerd. Voorts is aangegeven dat het van belang is dat, indien beleid inzake internal control of procedures vragen oproept, tijdig verbetermaatregelen en/of correcties worden doorgevoerd (COSO, 2013, p. 141).

Daarnaast is aangegeven dat het management periodiek het beleid inzake internal control en de procedures met betrekking tot control activities moet beoordelen in relatie tot de veranderingen in doelstellingen en/of risico's, bezetting, processen en/ of ICT-toepassingen. De waarborging van de werking van de control activities heeft veel meer aandacht gekregen in het IC-framework 2013 dan in het IC -framework 1992. 
13. The organization obtains or generates and uses relevant quality information to support the functioning of other components of internal control

$\mathrm{Bij}$ dit principe is aangegeven dat met het continu functioneren van de informatiesystemen de andere componenten van internal control worden ondersteund. Dit stelt ook eisen aan de informatie en communicatie. In hoeverre deze eisen haalbaar zijn hangt sterk af van de informatie- en communicatiebronnen en -kanalen.

De bronnen en kanalen nemen nog steeds toe. Deze nieuwe bronnen en kanalen komen expliciet naar voren in het IC-framework 2013. Hierbij wordt aandacht besteed aan ERP-systemen met data warehouses, smartphones en social media. Dit aspect krijgt meer aandacht in het IC-framework 2013 dan in het ICframework 1992.

14. The organization internally communicates information, including objectives and responsibilities for internal control, necessary to support the functioning of internal control

Bij dit principe wordt, meer dan in het IC-framework 1992, expliciet de link gelegd tussen de interne informatievoorziening en de elementen uit de control environment zoals communicatie over de verantwoordelijkheden. Er wordt aandacht besteed aan de communicatie over de doelstellingen en wat ten aanzien van deze doelstellingen van de medewerkers wordt verwacht.

Ook wordt in het IC-framework 2013 aandacht gevraagd voor de communicatie tussen het management en de leiding en toezichthouders om goed toezicht mogelijk te maken op de werking van de internal control. In de verdere uitwerking wordt aangegeven dat het van groot belang is dat deze communicatie met de juiste frequentie en de juiste mate van detail plaatsvindt. Dit wordt sterk bepaald door de dynamiek in de interne en externe omgeving. Voorts wordt aangegeven dat het belangrijk is dat andere medewerkers dan het management rechtstreeks toegang hebben tot de leiding en de toezichthouders. Wat voor interne informatie en communicatie geldt, geldt eveneens voor informatie van en communicatie met derden.

Bij dit principe wordt ook aangegeven dat er specifieke communicatiekanalen moeten zijn voor snelle overdracht van vertrouwelijke zaken. In het IC-framework 2013 wordt hierbij aangegeven dat de reguliere informatie- en communicatiekanalen hiervoor niet geschikt zijn.

Ook wordt bij dit principe aangegeven dat medewerkers het gevoel moeten hebben dat managers naar hun problemen willen luisteren en zo nodig de juiste acties willen ondernemen. Dit is een essentieel onderdeel van dit principe. Bij communicatie moet ook de juiste methode worden gekozen. Dit is sterk afhankelijk van de situatie. In het IC-framework 2013 worden allerlei moderne en klassieke methoden aangegeven. Ook worden criteria aangegeven die van belang zijn voor de keuze van de specifieke methode.

15. The organization communicates with external parties regarding matters affecting the functioning of internal control $\mathrm{Bij}$ dit principe wordt specifiek ingegaan op mechanismen om informatie te verkrijgen over trends, gebeurtenissen en omstandigheden die impact hebben op het realiseren van doelstellingen. Deze informatie moet intern gedeeld worden. Dit is essentieel om tijdig veranderingen in de externe omgeving te onderkennen. Hiermee speelt het IC-framework 2013 in op de dynamiek in de externe omgeving. Ook wordt bij dit principe aangegeven dat externe communicatie van belang is om externe partijen in kennis te stellen van de waarden, de cultuur en de internal control van de organisatie.

Bij dit principe wordt ook een relatie gelegd met "in control statements" van dienstverleners en verklaringen van accountants met betrekking tot de internal control ten aanzien van financiële en niet-financiële rapportages van de organisatie. Dit is ook een belangrijke aanpassing ten opzichte van het IC-Framework 1992.

16. The organization selects, develops and performs ongoing and/or separate evaluations to ascertain whether the components of internal control are present and functioning

Bij dit principe wordt in aanvulling op de punten genoemd in het IC-framework 1992 aandacht besteed aan het monitoren van de internal control bij service providers. Onderscheid wordt gemaakt in zelf uitvoeren van monitoring activiteiten bij de service provider, via een onafhankelijk auditor of via de normale informatievoorziening.

17. The organization evaluates and communicates internal control deficiencies in a timely manner to those parties responsible for taking corrective actions, including senior management and the board of directors, as appropriate

Bij dit principe wordt naar aanleiding van corporate governanceregelgeving ingegaan op het evalueren van en het communiceren over tekortkomingen in de internal control. Dit is regelgeving die na 1992 is uitgekomen en waarmee dus nog geen rekening kon worden gehouden ten tijde van het opstellen van het oorspronkelijke IC-framework. Dit aspect is dan ook veel meer uitgewerkt in het IC-framework 2013. Aangegeven wordt dat tekortkomingen moeten worden gerapporteerd aan de verantwoordelijke medewerker en het management. Hiermee is het toezicht op het verbeterproces ook georganiseerd. 


\section{Hoe is rekening gehouden met de kritiek op het oorspronkelijke IC-framework en op concepten van het geüpdate framework?}

In september 2010 is gestart met de ontwikkeling van dit geüpdate framework. De eerste fase van het ontwikkelingsproces bestond uit een literatuurstudie, het uitzetten van enquêtes en het organiseren van conferenties om de meningen en ervaringen met betrekking tot het IC-framework 1992 te inventariseren. Dit leidde tot (COSO, 2012):

- updates, verbeteringen en verduidelijking van het framework inzake significante wijzigingen in de businessomgeving en de hiermee verband houdende risico's;

- het codificeren van criteria voor het ontwikkelen en beoordelen van een internal control-systeem in de vorm van principes;

- meer focus op de bedrijfsuitvoering, compliance en niet-financiële rapportages.

Concepten van het geüpdate framework die in de tweede fase van het ontwikkelproces onder begeleiding van een Advisory Concil, samengesteld uit regelgevers, beroepsorganisaties en de Big 4, zijn opgesteld, zijn in de periode december 2011 tot maart 2012 voor reacties uitgezet via diverse kanalen, zoals conferenties en online enquêtes. Hierop is vanuit allerlei landen door gebruikers en wetenschappers gereageerd. Er waren veel positieve reacties, maar ook suggesties. De belangrijkste suggesties waren (COSO 2012):

- beperk de mate van detaillering, zodat het geen checklist wordt;

- verstrek meer richtlijnen voor kleinere bedrijven en overheden;

- maak het framework toegankelijker, wat betreft het onderscheid tussen vereisten en richtlijnen;

- geef de relatie aan met het COSO Enterprise Risk Management- Integrated Framework;

- verduidelijk de wijze waarop het framework gebruikt kan worden bij het beoordelen van de effectiviteit ervan;

- verduidelijk de controls met betrekking tot outsourcing.

Deze suggesties zijn verwerkt in de definitieve versie van het geüpdate IC-framework en de bijgeleverde tools voor het gebruik ervan die, zoals eerder is aangegeven, op 14 mei 2013 zijn uitgebracht.

Ook is nagegaan of en hoe met dit geüpdate IC-framework tegemoetgekomen is aan de kritiek uit de Nederlandse literatuur op het IC- framework 1992.

Op hoofdlijnen komt de volgende kritiek op het ICframework 1992 uit de Nederlandse literatuur naar voren:
1. te ingewikkeld, te vaag en te abstract en onvoldoende uitgewerkt om in de praktijk toe te kunnen passen (Soeting \& Spoor, 2003; Paape et al., 2009);

2 . het is een generiek raamwerk met generieke aandachtspunten en beoordelingscriteria (Renes, 2003);

3. lijkt uit te gaan van top-downgeleide organisaties (De Groot, 2007);

4. geeft geen harde beoordelingscriteria (Renes, 2003; Van Leeuwen \& Wallage, 2010);

5 . geeft geen richtlijnen voor de onderlinge weging van de componenten en deelcomponenten (Renes, 2003; Van Leeuwen \& Wallage, 2010);

6. interne beheersing wordt voornamelijk uitgewerkt in aandachtspunten die een formele, rationeel economische achtergrond hebben (Renes, 2003);

7. er is sprake van een gesloten systeembenadering (Renes, 2003);

8. niet-formele factoren die bepalend kunnen zijn om activiteiten te beheersen en vooral om de gekozen strategie te beheersen worden wel genoemd, maar niet uitgewerkt (Soeting \& Spoor, 2003; Van Leeuwen \& Wallage, 2010);

9. de implementatie en het aantonen van de werking van het IC-framework gaan met hoge kosten gepaard (Pruijm, 2007).

In hoeverre de vorengenoemde kritiek ook van toepassing is op het IC-framework 2013 kan als volgt worden toegelicht:

Ad 1en 2. te ingewikkeld, te vaag en te abstract en onvoldoende uitgewerkt om in de praktijk toe te kunnen passen en een generiek raamwerk met generieke aandachtspunten en beoordelingscriteria

Uit vorenstaande kritiekpunten blijkt een verwachtingskloof met betrekking tot de doelstelling van het IC-framework 1992 te bestaan. Het IC-framework 1992 is een framework en geen uitgewerkt handboek voor de opzet en het toetsen van de werking van internal controls. Het IC-framework 1992 bestaat uit een aantal componenten die samen een raamwerk voor internal control vormen. In het IC-framework 1992 is aangegeven dat internal control een gedeelte van het management proces omvat (COSO, 1994, p. 21). Het bepalen van ondernemingsdoelstellingen, het formuleren van de missie en waarden, het uitvoeren van een strategische planning en risicomanagement en bijsturingacties vallen buiten internal control volgens het IC-framework 1992. Ook de bij het IC-framework 1992 opgenomen evaluatiepunten en evaluatietools bevatten slechts voorbeelden en aandachtspunten die nader uitgewerkt moeten worden in de specifieke situaties. Het management is verantwoordelijk voor de implementatie en de juiste werking van internal control binnen het managementproces (COSO, 1994, p. 83). Toezichthouders hebben volgens het IC-framework een 
belangrijke rol in het formuleren van verwachtingen met betrekking tot integriteit en ethische waarden en houden toezicht op de realisatie daarvan (COSO, 1994, p. 86).

In het IC-framework 2013 is aangegeven dat het geüpdate Internal control - Integrated framework organisaties ondersteunt bij het effectief en efficiënt ontwikkelen en onderhouden van internalcontrolsystemen die de kans op het behalen van de ondernemingsdoelstellingen en aanpassing daarvan aan veranderingen in de interne en externe omgeving kunnen verhogen (COSO, 2013, p. 30). Ook in het IC-framework 2013 is aangegeven dat het bepalen van ondernemingsdoelstellingen die een geheel vormen met de missie, de visie en de strategie van organisaties keuzes zijn van het management en de toezichthouders. Deze doelstellingen richten zich op de unieke positie van organisaties en op de relevante wet- en regelgeving voor de desbetreffende organisatie. Dit onderdeel van het managementproces is een eerste vereiste voor een systeem van internal control en een belangrijk onderdeel van het managementproces in relatie tot strategische planning (COSO, 2013, p. 39). Individuen die onderdeel uitmaken van het internalcontrolsysteem moeten de strategie en de doelstellingen van de organisatie kennen en snappen (COSO, 2013, p. 39). Een onderdeel van het systeem van internal control is dat het management passende doelstellingen formuleert zodat de risico's met betrekking tot het behalen van deze doelstellingen kunnen worden bepaald. Met deze toelichting op de doelstelling van het IC-framework 2013 en de scope ervan is duidelijk aangegeven wat gebruikers van het geüpdate IC-framework kunnen verwachten. Hiermee is de bestaande verwachtingskloof in opzet gedicht.

\section{Ad 3. lijkt uit te gaan van top-downgeleide organisaties}

In het IC-framework 2013 is expliciet aangegeven dat organisaties via diverse dimensies kunnen zijn gestructureerd (COSO, 2013, p. 77). Als voorbeelden worden genoemd product- of servicegericht, juridische structuren, geografische structuren, netwerkstructuren. De rapportagelijnen en de verantwoordelijkheids- en bevoegdheidstoedeling moeten op deze structuren aansluiten. Ook wordt in dit kader aandacht gevraagd voor ontwikkeling van de structuren in de tijd door allerlei omstandigheden. Ongeacht de specifieke structuur moeten de rapportage- en communicatielijnen zo zijn georganiseerd volgens het IC-framework dat de verantwoording over uitvoerende eenheden en functionele gebieden goed worden ondersteund door middel van deze lijnen.

Ad 4 en 5. geeft geen harde beoordelingscriteria en geeft geen richtlijnen voor de onderlinge weging van de componenten en deelcomponenten
De beoordelingscriteria en de richtlijnen voor de onderlinge weging van de componenten en deelcomponenten zijn nader toegelicht in hoofdstuk 3 "Effective Internal Control" van het IC-framework 2013. Uitgangspunt is dat alle componenten van internal control en de relevante principes aanwezig moeten zijn en functioneren en dat ze met elkaar één geheel vormen.

De zogenaamde "Deficiencies of internal controls" worden als volgt gedefinieerd: "een tekortkoming in een component of componenten en relevante principes die de kans beperkt dat een organisatie de doelstellingen realiseert" (COSO, 2013, p. 50).

Ad 6. interne beheersing wordt voornamelijk uitgewerkt in aandachtspunten die een formele, rationeel economische achtergrond hebben

In het IC-framework 2013 is bij de diverse principes aandacht besteed aan informele factoren van internal control. Voorbeelden hiervan zijn:

- principe 1: waarden, een leiderschapsfilosofie en een wijze van werken die in lijn ligt met de doelstelling van de organisatie;

- principe 2: expertise van toezichthouders;

- principe 4: ontwikkeling en continuïteit van personeel;

- principe 8: introductie van de fraudedriehoek;

- principe 12: beleid inzake internal control moet zijn gekoppeld aan individuele verantwoordelijkheden en het afleggen van verantwoording;

- principe 14: de link tussen de interne informatievoorziening en de elementen uit de control environment zoals communicatie over de verantwoordelijkheden.

Ad 7. er is sprake van een gesloten systeembenadering In het IC-framework 2013 wordt bij alle componenten en principes, voor zover relevant, ingegaan op relaties van de organisatie met de buitenwereld. Het betreft netwerken waarin de organisatie opereert, relaties met shared service organisaties of externe organisaties in het algemeen.

Ad 8. niet-formele factoren die bepalend kunnen zijn om activiteiten te beheersen en vooral om de gekozen strategie te beheersen worden wel genoemd maar niet uitgewerkt (Soeting హ Spoor, 2003; Van Leeuwen \& Wallage, 2010)

Vink en Kaptein (2008) werken uit wat bedoeld wordt met deze niet-formele factoren. Dit zijn de zogenaamde "soft controls". Soft controls worden gedefinieerd als: "de gedeelde percepties en ervaringen inzake de cultuur en het klimaat binnen de organisatie" (Vink \& Kaptein 2008, p. 257). Vink en Kaptein (2008, p. 258) noemen zeven factoren die als soft controls zijn te beschouwen: helderheid, voorbeeldgedrag, uitvoerbaarheid, betrokkenheid, transparantie, bespreekbaarheid 
en handhaving. Bij de in paragraaf 2 toegelichte principes $1,2,4,5,6,8,12,13,14,15$ en 17 van het ICframework 2013 staan deze soft controls centraal. Deze soft controls worden nader uitgewerkt bij deze principes, waarbij ook de zeven factoren nadrukkelijk aan de orde komen.

Ad 9. de implementatie en het aantonen van de werking van bet IC-framework gaan met hoge kosten gepaard

Het IC-framework 2013 gaat uit van principes. Het is aan het management om te bepalen welke principes zij belangrijk vinden en in welke mate zij deze uitwerken en implementeren. De focus op de belangrijke doelstellingen, de samenhang van de componenten en subcomponenten, de juiste mix van hard en soft controls en efficiënt en effectief omgaan met documentatie en monitoring is belangrijk om de kosten van implementatie en het functioneren van het IC-framework beperkt de houden. Hiervoor worden in het IC-framework 2013 diverse mogelijkheden beschreven.

\section{Conclusies}

Zoals uit het voorgaande blijkt, is het IC-framework 2013 een belangrijke stap voorwaarts. Het IC-framework 2013 is evenals het IC-framework 1992 opgebouwd uit vijf componenten die samen het control framework vormen. In het IC-framework 2013 zijn per component principes geformuleerd en zijn hiervoor aandachtspunten voor de inrichting en het functioneren van het framework gegeven. Dit is nieuw ten opzichte van het IC-framework 1992. Deze aandachtspunten zijn aangepast op de actuele omstandigheden en werkwijzen van organisaties. De verantwoordelijkheid voor de keuzes en invulling van de principes is nadrukkelijk bij het management neergelegd. Het toezicht op de invulling is neergelegd bij een toezichthoudend orgaan. Veel kritiekpunten met betrekking tot het oorspronkelijke IC-framework zijn weggenomen met het geüpdate framework.

Extra aandacht is in het IC-framework 2013 besteed aan de betrouwbaarheid van niet-financiële informatie, de expertise van toezichthouders, andere organisatievormen, netwerken, shared service centers, beloningssystemen, soft controls, fraude risico's en actuele ICT-toepassingen.

Voor organisaties die het IC-framework al toepassen is het IC-framework 2013 ook een grote sprong voorwaarts. Deze organisaties kunnen op basis van het geupdate framework tot een doeltreffender internal control komen door zich bij de herziening van het internalcontrolsysteem meer te focussen op de principes en aandachtspunten uit het geüpdate IC-framework dan op de regels die daarin als voorbeelden staan beschreven. Hierdoor ontstaat een duidelijker en transparanter IC-framework waarbij het management en de medewerkers de redenen zien van de controls die ze moeten naleven. Dit leidt tot goede discussies over het nut en de noodzaak van controls, een betere focus op de essentiële controls gericht op de doelstellingen van de organisatie en tot een grotere acceptatie van de controls bij het management en de medewerkers. Hierdoor wordt de betrokkenheid bij de controls ook vergroot, wat leidt tot een groter controlbewustzijn.

De implementatie dan wel aanpassing van een internalcontrolsysteem op basis van het IC-framework 2013 gaat niet vanzelf. Managers moeten zich ervan bewust worden dat zij keuzes moeten maken met betrekking tot de uitwerking van internal control vanuit zo duidelijk en concreet mogelijk geformuleerde organisatiedoelstellingen en een gekozen strategie om deze doelstellingen de bereiken. Tevens moet het management een risk appetite hebben bepaald. Dit betreft de bandbreedte waarbinnen de doelstellingen moeten worden gehaald. Toezichthouders moeten goed kunnen doorvragen naar de keuzes van het management inzake de inrichting van het systeem van internal control en kunnen nagaan of deze in het belang zijn van de organisatie. Ze moeten een discussie kunnen voeren met het management over de invulling van het internalcontrolsysteem in de volgorde componenten, principes en nadere uitwerking van de activiteiten ter zake van controls en in hoeverre deze waarborgen dat de doelstellingen binnen de vastgestelde bandbreedtes worden gerealiseerd. Auditors zullen het management en de toezichthouders moeten ondersteunen bij het vervullen van de vorengenoemde rollen en taken. Dit vergt een creatieve en professioneel-kritische houding van auditors. Ook zullen auditors zich meer moeten verdiepen in de aansluiting van de keuzes van het management op de risk appetite, de kwaliteit van de besluitvorming van het management inzake de doorvertaling van de principes naar de internalcontrolactiviteiten en of deze activiteiten gezamenlijk voldoende waarborg bieden dat de doelstellingen van de organisatie worden gehaald.

Het voorgaande betekent dat er bij veel organisaties iets moet veranderen in de bestaande rollen, taken en houdingen van de vorengenoemde spelers. Deze veranderingen raken veelal de cultuur van organisaties en de overleg- en toezichtstructuren. Ter ondersteuning van deze veranderingen is het belangrijk dat vanuit de wetenschap een grotere bijdrage wordt geleverd aan het nader uitwerken van theorieën onder het ICframework 2013 en dat organisaties bereid zijn hiervoor data te leveren. Via wetenschappelijk onderzoek wordt meer kennis en inzicht verkregen hoe tot een nadere invulling kan worden gekomen van systemen 
van internal control en welke factoren bij deze keuzes een rol kunnen spelen. Op dit gebied moet nog veel werk worden verricht.
J. Droogsma MSc RA is werkzaam als senior auditmanager bij de Auditdient Rijk en als docent bij Nyenrode

Business Universiteit, de Vrije Universiteit en de Rijks-

academie voor Financiën, Economie en Bedrijfsvoering.

\section{Noten}

Dit framework is in 1994 aangevuld met een addendum inzake rapportages over internal control aan externe partijen.

\section{Literatuur}

- COSO (1994). Internal control - Integrated framework. Geraadpleegd op www.coso.org.

- COSO (2012). An update of COSO's Internal control - Integrated framework. Geraadpleegd op www.coso.org.

- COSO (2013). Internal control - Integrated framework, framework and appendices. Geraadpleegd op www.coso.org.

- Groot, J. de (2007). Nieuwe COSO-leidraad voor kleinere ondernemingen: Praktische handvatten voor interne beheersing . De Accountant, 113(6), 34.

- Gupta, P.P., \& Thomson, J.C. (2006). Use of COSO 1992 in management reporting on internal control. Strategic Finance, 88(3), 27-33.

- Leeuwen, 0.C. van, \& Wallage, P. (2010). Het evalueren van de interne beheersomgeving, een onderbelicht thema. Maandblad van Accountancy en Bedrijfseconomie, 84(9), 447 457.

- Monitoring Commissie Corporate Governance
(2008). De Nederlandse corporate governance code. Beginselen van deugdelijk ondernemingsbestuur en best practice bepalingen. Geraadpleegd op http://commissiecorporategovernance.nl.

- National Commission on Fraudulent Financial Reporting (1987). Report of the national commission on fraudulent financial reporting. Geraadpleegd op http://www.coso.org/publications/ncffr.pdf.

- Paape, L., Swagerman, D., Prinsenberg, M., Scheffe, J., Star, J., \& Brecher, M. (2009). Risicomanagement in tijden van crisis (en voor en na). Geraadpleegd op http://www. nba.nl/Documents/Naktechnisch-thema/Corporate Governance/Nat. onderzoek Risicomanagement.pdf.

- Pruijm, R. (2007). Opinie: Waarom COSO? De Accountant, 113(6), 50.

- Public Company Accounting Oversight Board (PCAOB) (2007). Auditing Standard No. 5: An audit of internal control over financial reporting that is integrated with an audit of financial statements. Washington, DC: PCAOB.

- Renes, $\mathrm{R}$ (2003). COSO, wat valt er te repareren?. De Accountant, 109(10), 40-45.

- Savage, A., Norman, C.S., \& Lancaster, K.A.S. (2008). Using a movie using the COSO internal control framework: An instructional case. Journal of Information Systems, 22(1), 63 -76 .

- Simons, R. (2000). Performance measurement \& control systems for implementing strategy. Upper Saddle River, NJ: Prentice Hall.

- Soeting, R., \& Spoor, L. (2003). COSO na 10 jaar, AO na 100 jaar. Maandblad van Accountancy en Bedriffseconomie, 77(9), 408-415.

- Vink, H.J., \& Kaptein, M. (2008). Soft controls bii de rijkksoverheid. De oorzaken van rechtmatigheidsfouten onderzocht. Maandblad van Accountancy en Bedrijfseconomie, 82(6), 256-263. 